COUNTERFEIT CAPITAL 



\section{COUNTERFEIT CAPITAL}

Poetic Labor and Revolutionary Irony

Jennifer Bajorek

STANFORD UNIVERSITY PRESS

STANFORD, CALIFORNIA

2009 
Stanford University Press

Stanford, California

(C) 2009 by the Board of Trustees of the Leland Stanford Junior University.

All rights reserved.

No part of this book may be reproduced or transmitted in any form or by any means, electronic or mechanical, including photocopying and recording, or in any information storage or retrieval system without the prior written permission of Stanford University Press.

"The Bad Glazier" in The Parisian Prowler by Charles Baudelaire, translated by Edward K. Kaplan, printed by permission of the University of Georgia Press.

Chapter 2 was first published in Diacritics, Volume 33, Number I (Spring 2003). An earlier version of Chapter 4 was published in Qui Parle, Volume I6, Issue 2 (Spring/Summer 2007).

Printed in the United States of America on acid-free, archival-quality paper

Library of Congress Cataloging-in-Publication Data

Bajorek, Jennifer.

Counterfeit capital : poetic labor and revolutionary irony / Jennifer Bajorek. p. $\mathrm{cm}$.

Includes bibliographical references and index.

ISBN 978-0-8047-5824-6 (cloth : alk. paper)

I. Baudelaire, Charles, I82I-I867-Criticism and interpretation. 2. Marx, Karl, I8I8-1883. Das Kapital. 3. Irony in literature. 4. Capitalism in literature.

I. Title.

PQ2191.Z5B2355 2008

$84 \mathrm{I}^{\prime} .8-\mathrm{dc} 22$ 